\title{
Ratih Kumala's Novel Tabula Rasa and the Promotion of Inclusiveness in Indonesia
}

\author{
Mytha Candria \\ \{mythacandria@live.undip.ac.id\} \\ Universitas Diponegoro, Indonesia
}

\begin{abstract}
Through her novel Tabula rasa, Ratih Kumala has made attempts to promote inclusiveness in Indonesia, where inclusiveness is defined with reference to pluralism and equality. An inclusive society is thus a society where all its members-despite their genders, ethnicities, religions, languages, sexual orientations, social classes, etc.- are treated equally, meaning that they have equal access to power, politics, economy, education, the law, health care, and other needs. Unfortunately, Indonesia has not thus far become inclusive, for there are women, children, and other minority groups who experience discriminations, abuses, and violence. Indonesia is patriarchal and exclusive. This is what Ratih Kumala opposes in the novel, since what she longs for is an inclusive Indonesian society, where women, children, and the minority are equal to men and the majority.
\end{abstract}

Keywords: Tabula Rasa, Inclusiveness, Indonesia.

\section{Introduction}

Tabula Rasa [1], the third winner of the novel-writing contest held by Jakarta Arts Council (Dewan Kesenian Jakarta) in 2003, presents the love stories of the male protagonist Galih and the female protagonist Raras. Galih, the son of an Indonesian ambassador, fell into a Russian girl Krasnaya when he was studying at Moscow State University in the 1990-s. Unfortunately, their love story had come to an end because Krasnaya was shot dead by the $\mathrm{KGB}$, the main security agency for the Soviet Union, who was suspicious of their relationship. The agency was suspicious that Galih-Krasnaya relationship had something to do with politics, since Galih's father was an Indonesian ambassador, and Indonesia back then was known to have good connection to America, the most unwanted rival of the Soviet.

Krasnaya's tragic death left Galih so broken-hearted that he was unwilling to get involved in any romantic relationships for a decade until he met Raras, a student of his at Gadjah Mada University, Yogyakarta. He was in love with her and they started a romantic relationship. However, this was not a mutual romance, since Raras was a lesbian. She covered her true sexual orientation because she was afraid of the high social cost, she, and her family, would have to pay if she disclosed it.

Raras was a Javanese girl, who was expected by her family to get married to a decent man and to start a family of her own. She was expected to fill the role most Javanese women of her time played: to become a wife and a mother. This pressure depressed her because she 
could only fall into women. No matter how hard she tried, she could not love Galih. In the end, Raras left Indonesia for Canada, where she could openly live as a homosexual.

Ratih Kumala's decision to make a lesbian her protagonist has attracted the attention of some researchers. Tabula Rasa has been studied from the perspectives of psychology of literature [2][3], sociology of literature [4], structuralism [5], and feminisms [6][7][8]. However, it would be impossible to discuss all the studies within the scope of this paper. Yet, the point that Yasnur Asri and Yenni Hayati [4] and Wiyatmi [6][9] put forward is worth mentioned here. They argue that Raras's lesbianism is one-way Kumala criticizes patriarchy, which represses women. Also, lesbianism indicates the influence of radical feminism on the novelist; radical feminists view homosexuality as a way women liberate themselves from men's subjugation and domination [4][6][9].

Thus far, none of the previous studies of Tabula rasa relates it to the promotion of inclusiveness within Indonesian context. This is why I have been interested in studying the idea of inclusiveness in the novel. 'Inclusive', in the Merriam-Webster dictionary [10], is defined as "including everyone; especially: allowing and accommodating people who have historically been excluded (as because of their race, gender, sexuality, or ability)". This suggests that inclusiveness relates to a situation or condition where every member of the society or community, despite their "ethnicity, language, politics, religion or whatever", is embraced [11]. This is why the former Secretary State for Wales Ron Davies sees inclusiveness as leading to pluralism [11]. Also, inclusiveness suggests equality for everyone. Hence, CARE India, an NGO working for the well-being of Indians, states that in their efforts to promote inclusive governance, its personnel's are to focus on three major areas, the first of which centers on empowering Indian women and girls because they are among the marginalized within the context of Indian development [12]. Here, the acts of promoting inclusiveness includes the acts of assuring equality for all the community members; this is why actions to empower the marginalized and minority groups become requirements for an inclusive society.

\section{Research Method}

The aim of this study is to describe the promotion of inclusiveness in the novel Tabula rasa; to reach the objective, I use feminist stylistics [13] as the theoretical framework. Feminist stylistics, according to Sara Mills:

aims to lead stylistics away from analysis of the language of the text, ..., to an analysis of socioeconomic factors which have allowed that language to appear, or which have determined its appearance, or which have determined the type of interpretations of that text which are possible [13]

Mills [13] holds that:

Most feminists hold a belief that women as a group are treated oppressively and differently from men and that they are subject to personal and institutional discrimination. Feminists also believe that society is organized in such a way that it works, in general, to the benefit of men rather than women; that is, that it is patriarchal. 
This does not mean she claims that all men are benefited from patriarchal society and that all women experience similar discrimination and oppression. She believes that society is also repressive to men "in different degrees", and that not all men celebrates patriarchy, for there are men who choose to oppose patriarchal structures and traditions [13]. Mills also emphasizes the fact that, like men, women are not the same. They are different individuals; thus, saying that all women suffer equally from patriarchy is a simplification. However, "most feminists would still maintain that women are systematically discriminated against as a group, albeit in a variety of ways" [13]. Feminism, as Mills puts it, "implies commitment to changing the social structure to make it less oppressive to women, and, for that matter, to men" [13].

\section{Result and Discussion}

First published in 2004 and reprinted in 2014 and 2016, Tabula rasa is a reformation-era novel. This means that to understand the novel, we need to recall our background knowledge regarding Indonesia's reformation. Reformation period, beginning with the fall of President Soeharto in 1998, was marked by, among others, the euphoria of freedom of speech after thirty-two years of silence. Soeharto, ruling the country in the so-called New Order period (1966/1967-1998), run corrupt, manipulative, and oppressive governance. He led Indonesia in a way that would benefit him and his cronies the most; KKN (korupsi, kolusi, dan nepotisme 'corruption, collusion, and nepotism') were pervasive in almost all sectors of his governance. On top of it, Soeharto were intolerant to criticisms and dissent. Those daring to say contending ideas or criticize the government would be quieted.

Soeharto controlled every sector of the nation life, and literature was no exception. The works of literature that were not in line with the state ideologies or policies would be banned [14]. A number of novels became the loudspeaker of the state ideologies, including those which exclude and marginalized women. The novels described good female characters as wives and mothers. Good women got married, stayed at home, and dedicated their lives to the families.

The fall of Soeharto in 1998 started the era of reformation and opened the door to freedom of speech. Novel publications were mushrooming, and women wrote novels that criticized hypocrisy, discrimination, repression, and violence. The previous state ideology that positioned women secondary to men was resisted. The false consciousness that women were but wives and mothers was challenged, and the idea that women should have been submissive and domesticated was opposed.

Concerning women writers of the reformation era, Triwokromo [15] writes that Indonesian women have fought for the rights of women not only in the parliament but also in literature. Through their novels or short stories, female authors such as Ayu Utami, Ratih Kumala, Nukila Amal, Linda Christanty, and Djenar Maesa Ayu express their concerns about Indonesian women: they want justice and equality for women; they oppose patriarchal traditions, which are unjust and exploitative. These feminist authors, in the words of Sara Mills [13], "commit to change the social structure to make it less oppressive to women, and, for that matter, to men".

Ratih Kumala, in Tabula rasa, resists patriarchy, which tends to be exclusive, through the female protagonist Raras, a courageous, educated, and independent woman. Raras refuses to submit to any forms of repression that she has to face as an Indonesian girl of Javanese origin; she insists on following her own calls, including becoming a lesbian. In this point, it is 
relevant to argue that through Tabula rasa, Kumala [1] wants women to be empowered in that they dare to criticize and resist discrimination, injustices, exclusion, and repression, prescribed and practiced by the society. For example, she wants women to contests the thoughts that women have to get married and subsequently to be submissive to their husbands. She uses the word "naïve" and the phrases "too cliché", "too Eastern", and "too Javanese" to express her disagreements to the society's patriarchal standards:

"Yu, bisakah beri tahu aku kenapa aku harus menikah?” tanya Raras pada Yu Marsini

"Karena kau perempuan, Nduk. Cah ayu yo kudune menikah, punya suami lantas mengabdi. Kuwi kodrate wong wedhok." Itulah kodratnya perempuan. ${ }^{\text {a }}$

Raras terdiam. Tidak bisakah wanita ini memberi jawaban yang memuaskannya? Jawaban yang tidak terlalu klise. Terlalu Timur. Terlalu Jawa. Tak diungkapkannya, Raras merasa lebih baik diam.

Ah...lugu sekali pemikiran orang-orang ini, tak tahukah zaman sudah bolakbalik? Apa yang akan mereka katakan kalau tahu aku lebih suka pada perempuan? Pada Violet! Bisa-bisa pada gantung diri [1].

"Yu, can you tell me why I have to get married?" asked Raras to her maid Yu Marsini. "Because you're woman, Nduk. Girl must get married, have a husband, and serve him. This is woman's inherent nature". Raras fell quiet. Couldn't this woman give her a sophisticated answer? Hers was too cliché. Too eastern. Too Javanese. Remaining silent, she felt she better said nothing.

Ah, how naïve these people were, didn't they know time had turned upside down? What would they say had they known I was into women? Into Violet! They would hang themselves).

(On page 106, Mother (ibu) tells Raras that to cook and to serve the husbands are women's inherent nature (kodrat)).

Yu Marsini and $i b u$ are symbols of old generation, a generation born and brought up in old patriarchal traditions, and they hold on to patriarchal standards, where women are excluded from the publics. Women are to remain at home and to care for the domestic chores, as what $i b u$ said to Raras that the inherent nature of women is to cook in the kitchen. Women are subordinate to men, as are indicated in the words chosen by Yu Marsini and ibu: ngladeni and mengabdi, meaning to serve, to dedicate, and to submit. It is women's inherent nature (kodrat) that they submit to the will of their husbands.

The exclusion of women from public domain and the obligation for women to submit to men's supremacy are resisted by Raras. Although she does not say anything in return to $\mathrm{Yu}$ Marsini's utterances, she expresses in a direct thought her disagreement with Marsini's perspective: "Tidak bisakah wanita ini memberi jawaban yang memuaskannya?" This disagreement is supported by further evaluation concerning Javanese patriarchy: too naïve, to

\footnotetext{
${ }^{a}$ In the novel, the underlined words are printed in italics because they are in Javanese, not in Indonesian. Yu Marsini frequently switches to Javanese language, which may be interpreted as Kumala's directing her criticisms to Javanese sexist teachings and practices.
} 
cliché, too Eastern, to Javanese. Time has changed (and Indonesians, including Javanese, need to change as well, and the old beliefs and practices need to be critically evaluated).

How can this resistance to sexism relate to the author's promotion of inclusiveness? Inclusiveness, as has been mentioned earlier, is a condition where all the community members are embraced and accommodated. Inclusiveness requires pluralism and equality. When women are still discriminated and subordinated, inclusiveness, and thus inclusive society, will remain a dream. This suggests that women empowerment is required, and women empowerment is what Kumala wants to communicate through the piece of narration between Raras and $\mathrm{Yu}$ Marsini.

Women are empowered if they earn good education; education opens up minds and equip women with important skills. Education enables Raras to have vast knowledge, making her critical and assertive. Women, especially those of young generations, need to be critical of the commonly held beliefs and traditions because some of them are not fruitful. For example, they discriminate women, they restrict women from active involvement in public spheres, or they prevent women from reaching their full potentials. Powerless women will only lead to exclusive, unjust, and unhealthy society, which should not be let to happen in this period of time.

The promotion of inclusiveness is also reflected in the larger picture of Kumala's characterization of Raras. Raras is a woman of strong characters. She is independent, smart, technologically literate, and cosmopolitan. All these qualities benefit her in that they enable her to assert her standpoints, to get rid of social pressure, and to become part of a more inclusive society, where she is respected and treated equally. Empowered women contribute to an inclusive Indonesia.

Technological literacy, including internet literacy, is also imperative because literacy in technology and the internet provides women access to the global, international world (for instance, see [1]). This makes it possible for them to learn international issues, obtain new knowledge, or discover the latest scientific findings, all of which will be beneficial for women to be empowered individuals who, in the end, can empower others as well.

Leaving aside the discussion of women empowerment and turning into Raras's lesbianism, we need to see it within broader contexts. Raras was born heterosexual; she was thus a tabula rasa. She turns homosexual through a long process. Raras's first traumatic experience occurred when Rimbang, her twin, died of child sexual abuse at the age of five. This has then worsened by her father's attitude; he has always been cold and aloof, unlike her mother and her maid Yu Marsini, who always welcome her with affection.

Child sexual abuse that Rimbang experienced necessitates law enforcement. The rate of violence and sexual abuses towards women and children in Indonesia is continuously increasing, but thus far there has not been the law that can protect women and children from any kinds of abuses, be they verbal, psychological, physical, or sexual. Beside women and children, the minority people, such as homosexuals, are also vulnerable to discrimination and harassment. Inclusiveness suggests equality in all sectors of life. However, for the citizens of Indonesia, there have not been equal rights to justice, protection, and security.

\section{Conclusion}

Novel writing is one way an individual can use to communicate her concerns about what happens in her society. Tabula rasa, for example, is written by Ratih Kumala as a response 
toward exclusiveness in Indonesian society, particularly in Javanese society. Javanese is exclusive in that women are treated differently from men. For instance, women have to submit to their husbands once they get married.

Javanese is exclusive because it is patriarchal, and patriarchy gives privilege to men over women and children. The minority is discriminated and repressed, while the majority benefits the most. This exclusion, and thus patriarchy, is opposed by Ratih Kumala in the novel Tabula rasa, for she wants inclusiveness in Indonesia. An inclusive society is a society where all its members, including women, children, and the minority, are respected and treated equally. This means that gender equality and women empowerment are mandatory if Indonesia is to be inclusive.

\section{References}

[1] R. Kumala, Tabula rasa (2nd ed.). Jakarta: Gramedia Pustaka Utama, 2016.

[2] I. Bahardur, "Ego Sintonik Tokoh-Tokoh Homoseksual Dalam Novel Indonesia Modern," Dialekt. J. Bahasa, Sastra, dan Pendidik. Bhs. dan Sastra Indones., vol. 1, no. 1, pp. 47-64, 2014.

[3] R. C. Caterine, Y. Asri, and M. I. Nst, "Perbandingan Perilaku Seksual Menyimpang dalam Novel Nayla dengan Novel Tabularasa," Pendidik. Bhs. Indones., vol. 1, no. 1, pp. 390-398, 2012.

[4] Y. Asri and Y. Hayati, "The Portrait of LGBT in Modern Indonesia Novels," in International Conference on Language, Literature, and Education (ICLLE 2018), 2018.

[5] I. R. Pratiwi, "Teknik Kolase Dalam Novel Tabula Rasa Karya Ratih Kumala," SKRIPSI Jur. Sastra Indones. Sastra UM, 2012.

[6] W. Wiyatmi, "Fenomena Seks dalam Novel Indonesia Mutakhir Karya Pengarang Perempuan: Kajian Kritik Sastra Feminis," Humaniora, vol. 18, no. 3, p. 11999, 2006.

[7] E. Suryani, "Novel Tabularasa karya Ratih Kumala (Tinjauan Feminisme Sastra dan Nilai Pendidikan)." UNS (Sebelas Maret University), 2010.

[8] A. A. Paramita, "Citra Wanita dalam Novel Tabula Rasa Karya Ratih Kumala: Tinjauan Sastra Feminis." Universitas Muhammadiyah Surakarta, 2010.

[9] Wiyatmi, Kritik sastra feminis: Teori dan aplikasinya dalam sastra Indonesia. Yogyakarta: Penerbit Ombak, 2012.

[10] Merriam-webster.com, "Merriam-Webster Online Dictionary." [Online]. Available: https://merriam-webster.com/dictionary/inclusive. [Accessed: 19-Jan-2020].

[11] P. Chaney and R. Fevre, "Inclusive governance and 'minority' groups: the role of the third sector in Wales," Volunt. Int. J. Volunt. Nonprofit Organ., vol. 12, no. 2, pp. 131-156, 2001.

[12] CARE India, "Inclusive governance." [Online]. Available: https://www.careindia.org/ourwork/inclusive-governance. [Accessed: 03-Oct-2019].

[13] S. Mills, Feminist stylistics. Routledge, 2002.

[14] B. Hatley, Postkolonialitas dan perempuan dalam sastra Indonesia modern. Sastra Indonesia modern: Kritik postcolonial. Jakarta: Obor, 2008.

[15] T. Triwikromo, "Perjuangan para perempuan di dalam kesusastraan," Harian Suara Merdeka, pp. 1, 9, 2019. 